\title{
Holocene marine transgression as interpreted from bathymetry and sand grain size parameters off Gopalpur
}

\author{
K MOHANA RAO, G V RAJAMANICKAM* and T C S RAO \\ National Institute of Oceanography, Regional Centre, Visakhapatnam 530023, India \\ *Department of Ancient Industries, Tamil University, Thanjavur 613005, India.
}

MS received 26 April 1988; revised 8 May 1989

\begin{abstract}
Grain size statistical parameters of the surface sediment samples collected from the innershelf off Gopalpur were calculated using graphic and moment methods. Fine-grained sand present up to $15 \mathrm{~m}$ water depth shows symmetrical skewness and good sorting. These are leptokurtic. The coarse-grained sand beyond $15 \mathrm{~m}$ water depth has positive or negative skewness and moderate sorting. These are platy kurtic. Bivariate plot of mean vs skewness indicates two types of sample spread, keeping approximately $2 \cdot 3 \phi$ mean as the demarcating boundary suggesting the presence of dune and beach types of sands. The study of log-probability sub-populations further supports these two types of sand as dune with single dominant saltation and beach with two distinct saltation populations. CM patterns suggest the role of rolling and graded suspension. The irregularity observed in bathymetry coincides with difference in the nature of sands within and beyond $15 \mathrm{~m}$ water depth. The behaviour of the grain size parameters and the associated bathymetric features suggest the presence of relict environments of dune and beach.
\end{abstract}

Keywords. Grain size statistics; innershelf sands; depositional environment; Holocene transgression.

\section{Introduction}

Although large amount of sedimentary analysis is being carried out in the eastern shelf sediments, a detailed study on grain size distribution appears to be lacking. Unlike the west coast of India, this shelf has widespread sandy sediments all along the coast. The fine sandy sediments near the coast are characteristically different from the coarse sands laying in juxtaposition, often inter-tonguing with them around $15 \mathrm{~m}$ water depth. They do not have any well-marked boundaries within them; however, their texture is quite different even to the naked eye. The present study is aimed at identifying the nature of depositional environments responsible for bringing about the co-existence of such contrasting sediments.

\section{Materials and methods}

A total of 127 bottom sediment samples were collected using the Van Veen Grab $\left(0.04 \mathrm{~m}^{2}\right)$ on a $15 \mathrm{~m}$ long mechanized boat. The sampling interval maintained was about $200 \mathrm{~m}$ up to $15 \mathrm{~m}$ water depth and more than $300 \mathrm{~m}$ beyond this level. The profiles were placed perpendicular to the coast at about $200 \mathrm{~m}$ interval. The position locations of the sampling stations obtained from three theodolite stations situated 




Figure 1. Sampling location and bathymetry off Gopalpur.

on the beach are plotted in figure 1. Echosounder (Simrad EQ) was used to record continuous bathymetry. The sediment samples were thoroughly washed and dried in the laboratory. Samples with significant organic matter were treated with $\mathrm{H}_{2} \mathrm{O}_{2}$ before final washing. The coned and quartered samples were sieved using sieves of half-phi $(\phi)$ interval. Statistical parameters (mean, standard deviation, skewness and kurtosis) of grain size were computed by the graphic (Folk and Ward 1957 and Folk 1974) and moment methods using Schlee and Webster (1967) programme. The values and their averages thus obtained are listed in table 1 . The bivariant plot for mean vs skewness was drawn following Moiola and Weiser (1968). CM pattern and log-probability curves for representative samples from different groups have been drawn following Passaga (1967) and Visher (1969) respectively.

\section{Results and discussion}

\subsection{Bathymetry}

The bathymetry of the area (figure 1) shows a steep gradient from 3 to $10 \mathrm{~m}$ water depth and becomes fairly smooth and gentle further seawards. Off Gopalpur creek, 
Table 1. Statistical parameters of sediment grain size

\begin{tabular}{|c|c|c|c|c|}
\hline \multirow[b]{2}{*}{ Parameters } & \multicolumn{2}{|c|}{ Graphic Method } & \multicolumn{2}{|c|}{ Moment method } \\
\hline & Range & $\begin{array}{l}\text { Average } \\
(n-127)\end{array}$ & Range & $\begin{array}{c}\text { Average } \\
(n-127)\end{array}$ \\
\hline Mean $\left(M_{z}\right)$ in $\phi$ & $\begin{array}{l}0.484 \text { to } \\
3.597\end{array}$ & $2 \cdot 280$ & $\begin{array}{l}0.481 \text { to } \\
3.567\end{array}$ & $2 \cdot 375$ \\
\hline $\begin{array}{l}\text { Standard deviation } \\
\left(\sigma_{l}\right) \text { in } \phi\end{array}$ & $\begin{array}{l}0.472 \text { to } \\
1.377\end{array}$ & $0 \cdot 716$ & $\begin{array}{l}0.477 \text { to } \\
1.337\end{array}$ & 0.730 \\
\hline Skewness $\left(S k_{l}\right)$ & $\begin{array}{c}-0.507 \text { to } \\
0.381\end{array}$ & -0.075 & $\begin{array}{c}-2.819 \text { to } \\
0.835\end{array}$ & -0.565 \\
\hline Kurtosis $\left(K_{G}\right)$ & $\begin{array}{l}0.669 \text { to } \\
1.487\end{array}$ & $1 \cdot 102$ & $\begin{array}{l}1.915 \text { to } \\
14.984\end{array}$ & $4 \cdot 689$ \\
\hline
\end{tabular}

a channel in NE-SW direction extends up to $15 \mathrm{~m}$ water depth. Thereafter, it changes into NNE-SSW direction and subsequently gets levelled ultimately disappearing beyond $25 \mathrm{~m}$ water depth. A marked ridge is seen between two valleys in the south western part of the study area resembling swale topography (Fisher 1968). A small shoal is seen at $10 \mathrm{~m}$ water depth in the north-eastern side of the creek. Such rapid changes in a short span of about one and half miles may be attributed to the relict feature.

\subsection{Graphic mean}

Distribution of graphic mean $M_{z}$ (figure 2a) indicates increase of grain size shoreward. When compared to the bathymetry of the area a steep gradient is associated with the presence of fine-grained sand $(>3 \phi)$ while the deeper areas with gentle gradient is comprised of coarse-grained sands $(<2 \phi)$. The frequency curves in figure 3 drawn for two groups of sands show the unimodal nature of the nearshore sands (figure 3B) and the bimodal nature of the deeper sands (figure $3 \mathrm{~A}$ ) which suggests the mixing of one additional population only in the nearshore basins which are brought to submergence.

\subsection{Standard deviation}

The graphic standard deviation $\sigma_{I}$ (figure $2 \mathrm{~b}$ ) indicates in general the prevalence of moderately sorted sediments. The distribution of the sorting marks the existence of better-sorted fine-grained sediments in the nearshore areas up to $15 \mathrm{~m}$ water depth, while the offshore coarser sands are of a moderate sorting nature and thus do not show any progressive trend. The deterioration in the sorting might have been induced due to the mixing of two well-marked populations, observed in the frequency distribution curves (figure $3 \mathrm{~A}$ ).

\subsection{Skewness}

The skewness $S k_{I}$ of the sediments (figure $2 \mathrm{c}$ ) varies from positive to vary negative and, in general, tends to positive seawards. Sediments beyond $25 \mathrm{~m}$ water depth are 

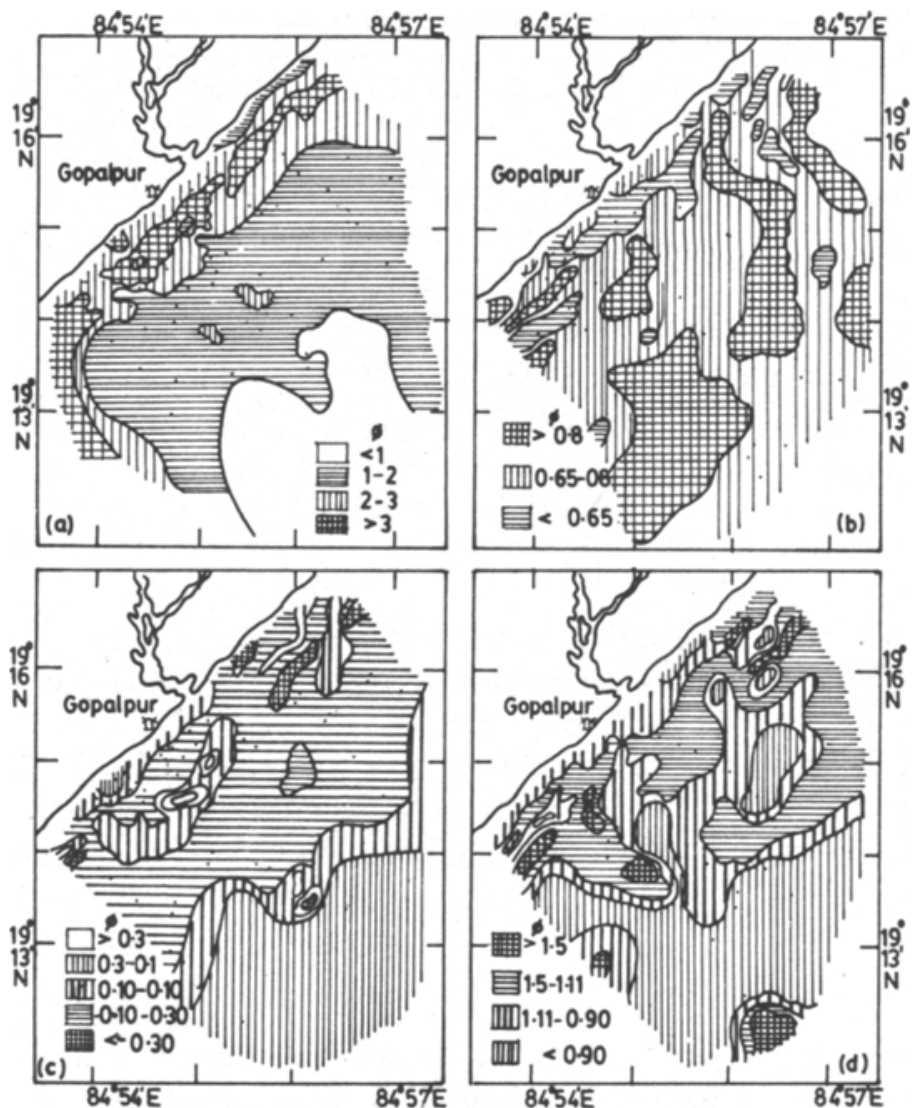

Figure 2. Distribution pattern of (a) graphic mean, (b) standard deviation, (c) skewness and (d) kurtosis.
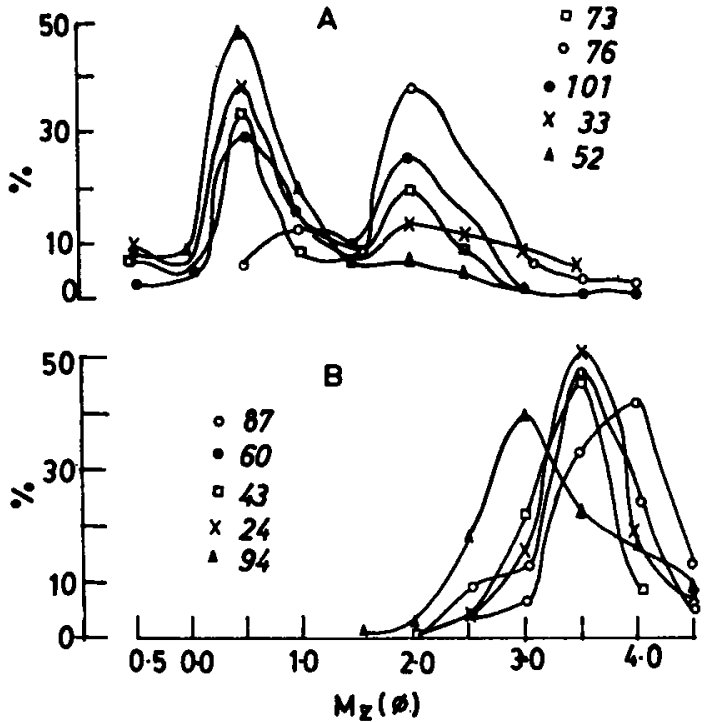

Figure 3. Frequency distribution of some representative samples of the area. 
positively skewed, while between 15 and $25 \mathrm{~m}$ they are negatively skewed and less than $15 \mathrm{~m}$ they are nearly symmetrical except for some small isolated pockets of both positive and negative skewness values which can be correlated to local topographic variation.

\subsection{Kurtosis}

The distribution of kurtosis values $k_{G}(0.68$ to 1.85$)$ (figure $2 \mathrm{~d}$ ) shows that the sands change from platykurtic to leptokurtic up to about $15 \mathrm{~m}$ and gradually reverse back to platykurtic. Beyond $15 \mathrm{~m}$ water depth, sediments that are mesokurtic/platykurtic show strong bimodal distribution. Such a kurtosis distribution indicates the unsorted spread of tail in the offshore as well as in the nearshore.

\section{Depositional environment}

Two types of sand that differ in texture exist in adjacent position without any distinct boundary. The occurrence of finer sands within $15 \mathrm{~m}$ depth followed by coarser sands beyond $15 \mathrm{~m}$ depth indicates a change in the distribution of sediments i.e. coarser in the seaward side and finer in the landward side. A bivariate plot (figure 4) of mean vs skewness following Moiola and Weiser (1968) suggests a distinct difference in environment of deposition for coarser sands as beach (marked in triangles) and finer sands as dune marked in circles (figure 4). The sands corresponding to dune $(>2 \phi)$

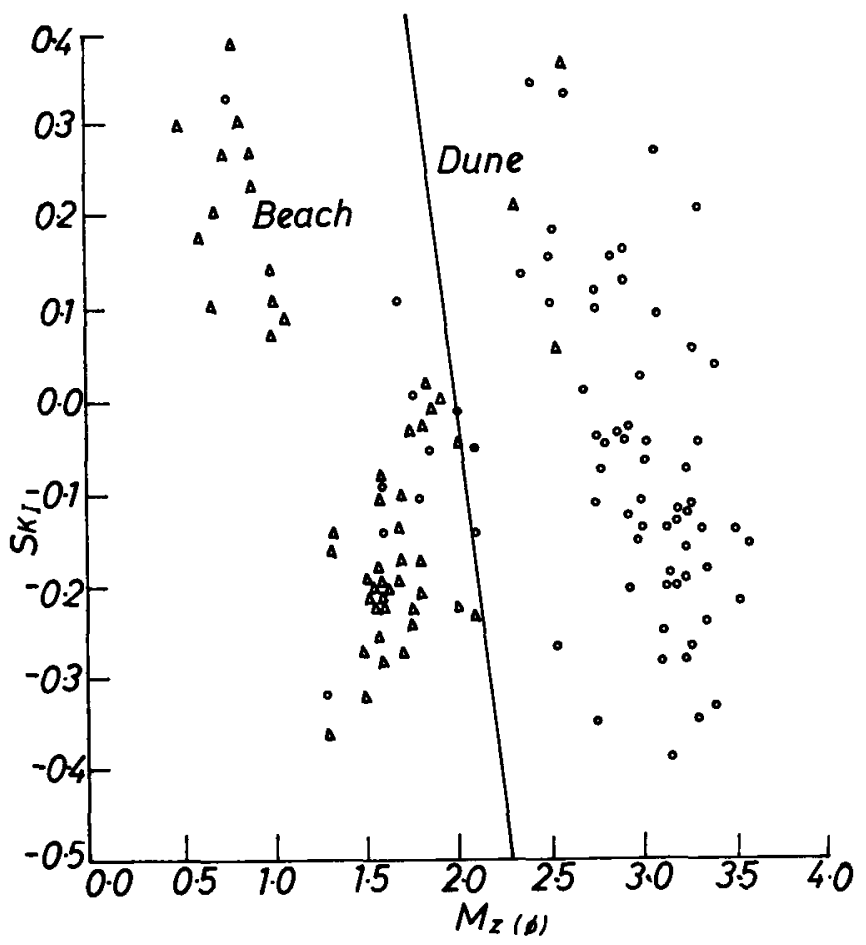

Figure 4. Bivariant plot of mean vs skewness (Moiola and Weiser 1968). 


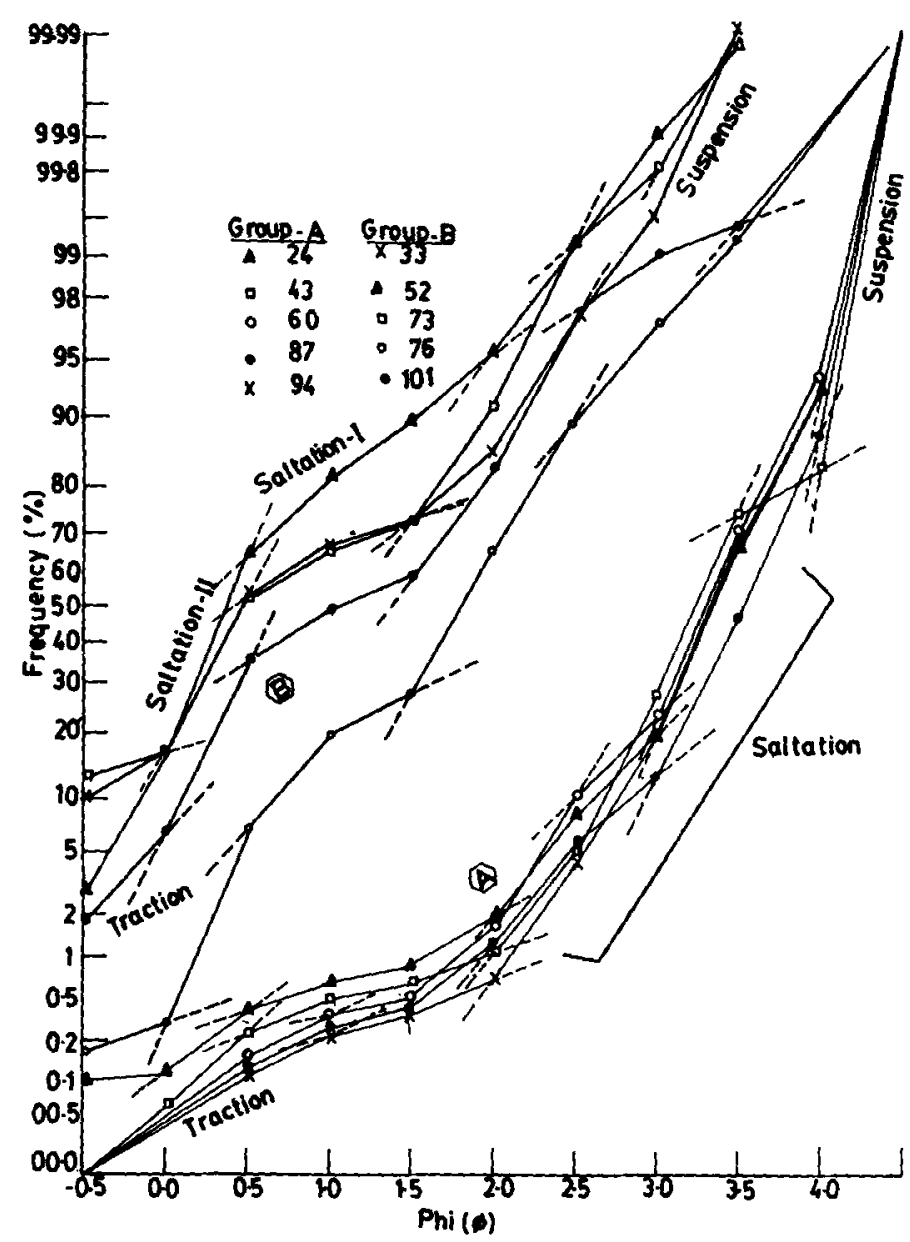

Figure 5. Cumulative frequency curves showing the straight-line segments for some representative sands off Gopalpur on probability paper.

in figure $5 \mathrm{~A}$ indicate three distinct sub-populations such as traction $(<2 \%)$, saltation $(90 \%)$ and suspension (about $10 \%)$ and the sands in the mean range of less than $2 \phi$ (figure 5B) comprise of two saltation populations $(80-90 \%)$, suspension population $(5-15 \%)$ and traction population $(1-10 \%)$. Such variation in the nearshore regions may be attributed to the difference in the turbulence level at the depositional basin. Sands beyond $15 \mathrm{~m}$ water depth are considered to have undergone relatively higher turbulence which may be ascribed to the products of foreshore beach sands (Passaga 1957). Friedman (1961) suggested negative skewness and unimodal frequency distribution to beach environments. Accordingly the sands in the mean range of 2 to $3 \phi$ are found to match well with negative skewness and of dominantly unimodal distribution whereas sands of less than $2 \phi$ mean size, though considered as beach sands, are noticed to be positively skewed with bimodal distribution. Hayes (1964) ascribed the absence of unimodal distribution for Padre Island beach as the cause for changing the skewness from negative to positive in the beaches. The depletion of fine-grained sands and the absence of grain size of more than $2 \cdot 74 \phi$ in beach sands 


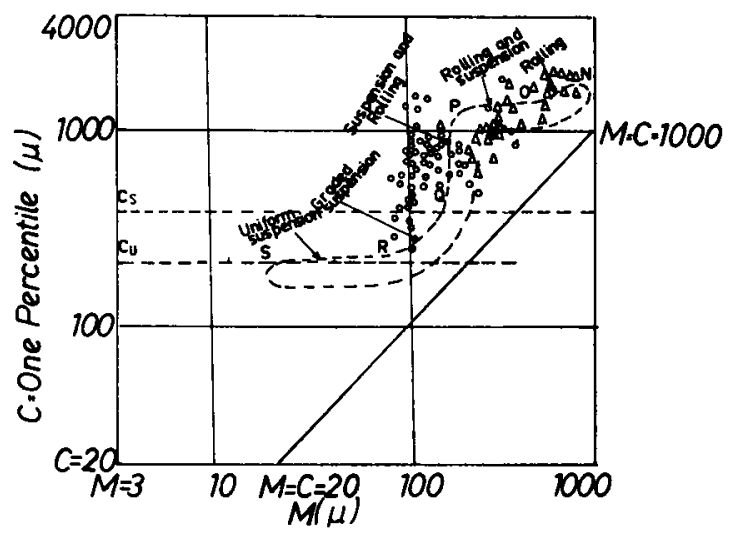

Figure 6. CM pattern for the sands off Gopalpur.

observed by Bagnold (1963) Miller and Zeigler (1964) and Ingle (1966) endorse the existence of beach environment.

The CM pattern of Passaga (1957) was prepared (figure 6) for the sands of both groups to enlighten the transport mechanism involved during deposition. The beach sediments $(\Delta)$ are found to occupy NO-OP segment representing the well-sorted sediments transported mainly by rolling and suspension. The amount of rolling and dispersion within the beach sands is attributed to the turbulent nature of the ancient beach condition caused primarily by the waves. This is also supplemented by the presence of coarse truncation of around $2.5 \phi$ for the finer end of the saltation population in samples of Figure 5B. On the other hand, the sands in PQ segment (O) are found to show a domination of graded suspension which is common in dunes. These sands show larger variation in ' $C$ ' rather than ' $M$ ' which is inferred by Passaga (1964) as a typical indicator of the influence of tractive currents with some amount of rolling in the formation of graded suspension. The lack of distribution gap in the CM patterns of the extended PQ segment (figure 6) and the limited spread in the median $(M)$ further suggest that the mechanism of both rolling and graded suspension had a role, hand in hand, in the deposition of these sands. Thus, the occurrence of graded suspension sands in this area is considered as the common feature of ancient sediments that are left uncovered by recent sediments (Passega and Byramjee 1969; Rajamanickam and Gujar 1985).

During the study of sediment movement in the littoral waters off Gopalpur, Shrivastava and Rao (1976) questioned the existence of modern sands and viewed the possible presence of relict sands. It is rather difficult to assimilate the occurrence of dune and beach environments in the shallow marine conditions. Similar occurrence of beach and dune sediments in the shallow marine conditions has also been reported from the study of grain size parameters along the Konkan coast in the western shelf of India (Rajamanickam and Gujar 1984, 1985 and 1988). This may therefore be surmised as the possibility of submergence of an ancient beach and dune along this coast. Subba Rao (1964) reported relict sands over the eastern shelf and showed that the shelf off Visakhapatnam has not been completely masked by recent sediments. A comparison of the variation in the world sea level chart of Bloom (1979) indicates the feasibilities of such transgression to a limit of about $40 \mathrm{~m}$. Therefore, the presence 
of ancient relict environments can also be assumed for the sands of these areas situated within $30 \mathrm{~m}$ water depth.

By applying the principle of shore parallel contour (Dietz 1963) along with the expected modern sediment coverage, the irregularities in the bottom topography might have been smoothened beyond $9 \mathrm{~m}$. Instead, the existence and appearance of irregular topography beyond $9 \mathrm{~m}$, that too, only for a narrow zone supplement the possibilities of relict feature, caused by submergence or transgression. As there is no direct evidence for submergence due to structural phenomena along the coast, and the feature noticed here is in resemblance to the reported barriers all along the North American and Australian coasts, caused by the Holocene Marine transgression (Fisher 1961; Curray 1964 and Swift et al 1971) the abrupt variation in the seabed topography may be ascribed to one such marine transgression during the Holocene period.

\section{Conclusions}

The characteristic negative skewness, moderate sorting with bimodal distribution and the lack of suspension materials indicate the existence of beach in the water depth beyond $15 \mathrm{~m}$. The studies of log probability sub-population and CM pattern also support the presence of beach environment for the sand beyond $15 \mathrm{~m}$ water depth and the sand below this level has been adjudged as dune type of environment. This beach and dune environments in the nearshore regions might have been caused by Holocene marine transgression. The behaviour of the textural pattern and associated bathymetric features suggest the presence of relict environments of dune and beach which leads to the conclusion that the beach ridges and channels observed up to $15 \mathrm{~m}$ contour are remnants of the earlier beach submerged during the Holocene transgression.

\section{Acknowledgements}

The authors thank Dr. B N Desai, Director, National Institute of Oceanography for encouragement, Shri S. Kannan for providing the positioning, bathymetry and other technical help, Shri M M Malleswara Rao for computer assistance and other colleagues who assisted in the collection of samples.

\section{References}

Bagnold B A 1963 Mechanics of Marine Sedimentation; in The Sea, ideas and observations on progress in the studies of the sea (eds) M H Hill, B D Goldberg, C O D Iselin and W H Munk (New York: John Wiley \& Sons) 3 507-528

Bloom A L 1979 Atlas of sea level curves (Cornell University).

Curray J R (1964) Transgression and regression in Marine Geology (ed.) R L Miller (New York: Macmillan Publishing Co. Inc.) pp. 531

Dietz R S 1963 Wave base, Marine profile of equilibrium and wave built terraces: A critical appraisal; Bull. Geol. Soc. Am. $74971-990$

Fisher J J 1968 Transactions National Symposium on Ocean Sciences and Engineering of the Atlantic Shelf (eds) A E Margolis and R C Steere (Washington DC: Marine Technological Society) pp. 143-149 
Fisher A G 1961 Stratigraphic record of transgressing seas in light of Sedimentation on Atlantic coast of New Jersey; Bull. Am. Assoc. Petrol. Geol. 45 1656-1666

Folk R L 1974 Petrology of Sedimentary Rocks (Hamphill, Austin, Texas) p. 182

Folk R S and Ward W C 1957 Brazos river bar: a study in the significance of grain size parameters; J. Sediment. Petrol. 27 3-27

Friedman G M 1961 Distinction between dune, beach and river sands from their textural characteristics; J. Sediment. Petrol. 31 151-163

Hayes M O 1964 Gulf Coast Assoc. Geol. Societies Field Trip guide book, Depositional Environments, South Central Texas Coast pp. 121-126

Ingle J C Jr 1966 The movement of beach sand (Amsterdam: Elsevier Publishing Co.) p. 221

Miller R L and Zeigler J M 1964 Marine Geology, Shepard Commemorative Volume (ed.) R L Miller (New York: Macmillan \& Co.) p. 133

Moiola R J and Weiser D J 1968 Textural parameters: An evaluation; J. Sediment. Petrol. 38 45-53

Passaga R 1957 Texture as characteristic of elastic deposition; Bull. Am. Assoc. Petrol. Geol. 41 1952-1984

Passega R 1964 Grain size representation by CM patterns as a tool; J. Sediment. Petrol. 34 830-847

Passega R and Byramjee R 1969 Grain size image of elastic deposits; Sedimentology 13 233-251

Rajamanickam G V and Gujar A R 1984 Sediment depositional environment in some bays in the Central West Coast of India; Indian J. Mar. Sci. 13 53-59

Rajamanickam G V and Gujar A R 1985 Indications given by median distribution and CM patterns on elastic sedimentation in Kalbadevi, Mirya and Ratnagiri bays, Maharashtra, India; Cioroale di Geologie 47 237-254

Rajamanickam G V and Gujar A R 1988 Depositional environment of the sediments in Konkan bays: Inferred from multi-group discrimination analysis using grain size distribution statistics; Indian $J$. Earth Sci. 15 234-247

Schlee J and Webster J 1967 A computer programme for grain size data; Sedimentology 8 45-53

Shrivastava R L and Rao B R 1976 A note on the relict sand (?) and movement of sediments of Gopalpur, Orissa Coast, India; J. Geol. Soc. India 17 401-404

Swift D J P, Sanford R B, Dill C E Jr and Avingnon N E 1971 Textural differentiation on the shore face during erosional retreat of an unconsolidated coast, Cape Henry to Cape Hatteras, Western North Atlantic Shelf; Sedimentology 16 221-245

Subba Rao M 1964 Some aspects of coninental shelf sediments off the east coast of India; Mar. Geol. $159-87$

Visher G S 1969 Grain size distribution and depositional processes; J. Sediment. Petrol. 39 1074-1106 